Rev. Int. Contam. Ambie. 37, 601-609, 2021

https://doi.org/10.20937/RICA.54011

\title{
STABILIZATION OF LEACHATE IN AGGREGATES MADE WITH PLASTIC FROM WEEE
}

Estabilización de lixiviados en agregados elaborados con plásticos de RAEE

\author{
Ariel CAPPELLETTI ${ }^{1}$, Lucas PEISINO ${ }^{1}$, Rosana GAGGINO ${ }^{1}$, Paula UBERMAN ${ }^{2}$, \\ Lucas COLMAN ${ }^{3}$ and Jerónimo KREIKER ${ }^{1 *}$
}

${ }^{1}$ Centro Experimental de la Vivienda Económica(CEVE)-CONICET, Av. Igualdad 3585, X5003BHG, Córdoba, Argentina.

${ }^{2}$ Instituto de Investigaciones en Fisicoquímica de Córdoba (INFIQC)-CONICET, Universidad Nacional de Córdoba, Haya de la Torre y Medina Allende, Córdoba, X5000HUA, Argentina.

${ }^{3}$ Departamento de Química Orgánica, Facultad de Ciencias Químicas, Universidad Nacional de Córdoba, X5000HUA Córdoba, Argentina.

*Author for correspondence: jkreiker@ceve.org.ar

(Received: May 2020; accepted: September 2020)

Key words: waste management, recycled plastic aggregate, brominated flame retardants, WEEE plastic

\begin{abstract}
A recycled plastic aggregate (RPA) was developed using the core-shell strategy, where the core is the plastic fraction of Waste of Electrical and Electronic Equipment (WEEE) and a cement matrix with stabilizing additives acts as the shell. The amount of brominated flame retardant (mainly tetrabromobisphenol-A) leached in curing water of RPAs was quantified using extraction with an organic solvent and gas chromatography methods (CG-FID). A clear relationship can be established between the characteristics of the stabilizing additive used and the amount of tetrabromobisphenol-A and bisphenol-A leached. The additive used was activated carbon, which in a manufacture scale may be provided by different suppliers with different mesoporous characteristics, which can be easily determined by the iodine number. The analysis proposed can be an effective way to determine if a particular activated carbon can be used as stabilizing additive in the production of RPAs with the developed technology.
\end{abstract}

Palabras clave: gestión de residuos, agregado de plástico reciclado, retardantes de llama bromados, plásticos de RAEE

\section{RESUMEN}

Se desarrolló un agregado de plástico reciclado (APR) usando la estrategia de núcleocoraza en que la fracción plástica de residuos de aparatos eléctricos y electrónicos (RAEE) es el núcleo o corazón y una mezcla de cemento y aditivos estabilizantes actúa como coraza. La cantidad de retardantes de fuego bromados (principalmente tetrabromobisfenol-A) lixiviados en agua para el curado de APR se mediante extracción con solventes orgánicos y cromatografía gaseosa (CG-FID). Se logró establecer una relación clara entre las características del aditivo estabilizante y la cantidad de tetrabromobisfenol-A y bisfenol-A lixiviados. Se utilizó como aditivo carbón activado, que en producción de gran escala puede ser provisto por diferentes proveedores 
comerciales con diferentes características de mesoporo. Esta característica puede evaluarse fácilmente mediante el número de iodo y es determinante en la capacidad de estabilización del carbón activado. El análisis propuesto puede utilizarse de manera efectiva con la tecnología desarrollada para determinar la capacidad estabilizante del carbón empleado como materia prima en la producción de RPA.

\section{INTRODUCTION}

Waste from electrical and electronic equipment (WEEE) grew significantly over the last 20 years (Tan et al. 2017). The plastic fraction of WEEE (WEEEP) represents about $20 \%$ of the total mass (Wäger et al. 2012). A real sample of WEEEP is a complex mixture of different types of polymers; yet, three types are predominant, acrylonitrile butadiene styrene (ABS, 30-35\%), high impact polystyrene (HIPS, 20-25\%) and polypropylene (20-30\%). Also, polycarbonate (PC) is present (Schlummer et al. 2007, Dimitrakakis et al. 2009a, Wäger et al. 2012, Peeters et al. 2014, Maris et al. 2015). It is widely know that this plastic contains heavy metals (Tamaddon and Hogland 1993, Dimitrakakis et al. 2009b, Stenvall et al. 2013), brominated flame retardants (BFRs) (Schlummer et al. 2005), polymer decomposition substances, and other hazardous compounds.

BFRs are persistent organic pollutants that can be accumulated and detected in humans and the environment (Meironyte et al. 1999, Covaci et al. 2006, Law et al. 2006). Over the last decades, concerns have been raised over the toxicity of some BFR compounds and their risk to human health (Darnerud 2003, Dunnick et al. 2017). Currently, it is difficult to recycle WEEEP and it is treated by incineration or landfilling (Ilankoon et al. 2018).

However, WEEEP could be used to develop novel recycled materials (Schlummer et al. 2006, Buekens and Yang 2014, Luhar and Luhar 2019), in particular novel building materials (Siddique et al. 2008, Saikia and de Brito 2012, Gu and Ozbakkaloglu 2016, Senthil-Kumar and Baskar 2018). An example of these are the recycled plastic aggregates (RPA) (Hannawi et al. 2010, Lakshmi and Nagan 2010, 2011, Wang and Meyer 2012, Alqahtani et al. 2014, 2017a, b, Nowek 2016), and the use of WEEEP as coarse aggregate for concrete (Senthil-Kumar and Baskar 2015a, b, c) and fiber for concrete mixture (Gu and Ozbakkaloglu 2016).

It is particularly important to analyze the impact of both contaminants (heavy metals and polybrominated organic compounds) in the final recycled material. In this way, Senthil-Kumar et al. (2016) and our research group considered the presence of metals in the leaching of Portland cement base materials made with WEEEP (Peisino et al. 2019). Also, we recently puy a study about the behavior of the BFRs present in WEEEP (specifically tetrabomobisphenolA [TBBPA]), in a Portland cement system (Gómez et al. 2020). We have determined that the hazardous organic contaminant (TBBPA) leached in a higher proportion when WEEEP was in contact with the basic medium of the Portland cement. However, this effect was solved with the use of activated charcoal (AC) as a stabilizing additive.

$\mathrm{AC}$ are composed of carbonaceous matter with a porous structure. They are generally manufactured in two stages: firstly by carbonization (pyrolysis) of the organic matter (essentially wood of different types), and then by an activation process (Yang 2003). The pyrolysis stage removes elements other than carbon, producing a porous material. The activation stage is necessary in order to increase the adsorption capacity of the material. There are many kinds of activation procedures that can be performed: physical activation (in presence of water vapor and air under pressure) or chemical activation (usually by treatment with phosphoric acid) (Yin et al. 2007). AC are particularly attractive for the capture of inorganic and organic contaminants due to their porosity (pore size ranging from 4.5 to $60 \AA$ ), good adsorption capabilities, relatively low production cost, and large specific surface area $\left(300-4000 \mathrm{~m}^{2} / \mathrm{g}\right.$ ) (Yang 2003). In addition, it is possible to modify the adsorption characteristics of activated carbons changing the raw material to be carbonized and by optimization of the carbonization process (Laine and Yunes 1992) and activation steps (Yin et al. 2007).

In this work we present the results on the deepening of the analysis of activated charcoal types and dosage. A core-shell approach was applied, where the particles of plastic wastes were covered with a mixture of masonry cement and activated charcoal. We evaluated the leached of TBBPA and bisphenol-A (BPA) in the curing water of the different formulations of RPAs. To achieve this, the extracts were analyzed by gas chromatography (GC) to determine the concentration of organic compounds leached and 
so evaluate the capability of the different activated charcoals to stabilize pollutants.

\section{MATERIALS AND METHODS}

\section{Reagents and materials}

WEEEP (WP) was supplied in crushed form by a local recycling company which collects and processes all types of waste of electric and electronic equipment. The apparent specific gravity of the used WEEEP was $510 \mathrm{~kg} \mathrm{~kg} / \mathrm{m}^{3}$. Masonry cement (MC) from Holcim was employed. Powder activate charcoals were obtained from different suppliers and were used as received. CAE 061, MMF, CAE Ultra and Clarisorb B were obtained from Clarimex; Merck was obtained from Merck. Powder vegetal charcoal ("Vegetal") was obtained from a local supplier. In order to obtain a homogeneous sample, the carbon was screened with a $75-\mu \mathrm{m}$ sieve (200 mesh).

Milli-Q water was employed for the preparation of RPAs and to carry out the curing of these materials. Analytical grade $n$-hexane, ethyl acetate, and hydrochloric acid $(\mathrm{HCl}, 37 \%)$ were used as they were received from the supplier. For iodine number determination the following reactants were used: potassium iodate $\left(\mathrm{KIO}_{3}\right.$, GR for analysis), potassium iodide (KI, GR for analysis), iodine $\left(\mathrm{I}_{2}, \mathrm{GR}\right.$ for analysis) sodium thiosulphate $\left(\mathrm{Na}_{2} \mathrm{~S}_{2} \mathrm{O}_{3}\right.$, GR for analysis), and starch.

TBBPA was obtained by column chromatography isolation in our laboratory with $99 \%$ purity determined by GC-MS. For quantification, two standards were employed: docosane $\geq 99 \%\left(\mathrm{C}_{22} \mathrm{H}_{24}\right)$, and 9-bromoanthracene $\geq 99 \%\left(\mathrm{C}_{10} \mathrm{H}_{15} \mathrm{Br}\right)$, both from Fluka.

\section{RPA manufacture}

The following procedure was used to manufacture the core-shell RPA, as described in a previous work (Gómez et al. 2020):

- First, the WP (core) was placed in the mixer and water was added to wet the plastic particles.

- Next, the cementitious mixture for the shell was added slowly and mixed by hand with enveloping movements.

- The shell was built in three layers, with a waiting time of $24 \mathrm{~h}$ between layers. In addition, particles were screened with a $4.8 \mathrm{~mm}$ sieve ( $4 \mathrm{mesh}$ ) between each layer.

- Finally, RPAs were cured by water immersion for 14 days.
Twenty-seven different RPAs were prepared. All samples were made using $250 \mathrm{~g}$ of WP covered with a mixture prepared with $300 \mathrm{~g}$ of MC, different amounts and types of $\mathrm{AC}$ and $100 \mathrm{~mL}$ of water (Table I).

TABLE I. RECYCLED PLASTIC AGGREGATES (RPAs) FORMULATIONS AND COMPOSITIONS ${ }^{1}$

\begin{tabular}{|c|c|c|c|}
\hline Entry & Sample & $\begin{array}{c}\text { Carbon } \\
\text { type }\end{array}$ & $\begin{array}{l}\text { Amount of } \\
\text { carbon }^{2} \\
(\mathrm{~g}, \%)\end{array}$ \\
\hline 1 & WP@MC & - & - \\
\hline 2 & WP@MC:CAE-1 & CAE 061 & $(6.25,1.1)$ \\
\hline 3 & WP@MC:CAE-2 & CAE 061 & $(12.50,2.2)$ \\
\hline 4 & WP@MC:CAE-3 & CAE 061 & $(18.75,3.3)$ \\
\hline 5 & WP@MC:CAE-4 & CAE 061 & $(25.00,4.3)$ \\
\hline 6 & WP@MC:MMF-1 & MMF & $(6.25,1.1)$ \\
\hline 7 & WP@MC:MMF-2 & MMF & $(12.50,2.2)$ \\
\hline 8 & WP@MC:MMF-3 & MMF & $(18.75,3.3)$ \\
\hline 9 & WP@MC:MMF-4 & MMF & $(25.00,4.3)$ \\
\hline 10 & WP@MC:CAEU-1 & CAE Ultra & $(6.25,1.1)$ \\
\hline 11 & WP@MC:CAEU-2 & CAE Ultra & $(12.50,2.2)$ \\
\hline 12 & WP@MC:CAEU-3 & CAE Ultra & $(18.75,3.3)$ \\
\hline 13 & WP@MC:CAEU-4 & CAE Ultra & $(25.00,4.3)$ \\
\hline 14 & WP@MC:CLARI-1 & Clarisorb B & $(6.25,1.1)$ \\
\hline 15 & WP@MC:CLARI-2 & Clarisorb B & $(12.50,2.2)$ \\
\hline 16 & WP@MC:CLARI-3 & Clarisorb B & $(18.75,3.3)$ \\
\hline 17 & WP@MC:CLARI-4 & Clarisorb B & $(25.00,4.3)$ \\
\hline 18 & WP@MC:MERCK-1 & Merck & $(6.25,1.1)$ \\
\hline 19 & WP@MC:MERCK-2 & Merck & $(12.50,2.2)$ \\
\hline 20 & WP@MC:MERCK-3 & Merck & $(18.75,3.3)$ \\
\hline 21 & WP@MC:MERCK-4 & Merck & $(25.00,4.3)$ \\
\hline 22 & WP@MC:VEG-1 & Vegetal & $(6.25,1.1)$ \\
\hline 23 & WP@MC:VEG-2 & Vegetal & $(12.50,2.2)$ \\
\hline 24 & WP@MC:VEG-3 & Vegetal & $(18.75,3.3)$ \\
\hline 25 & WP@MC:VEG-4 & Vegetal & $(25.00,4.3)$ \\
\hline 26 & WP@MC:VEG-19 & Vegetal & $(125.00,18.5)$ \\
\hline 27 & WP@MC:VEG-31 & Vegetal & $(250.00,31.3)$ \\
\hline
\end{tabular}

${ }^{1}$ All the RPAs were prepared with $250 \mathrm{~g}$ of WEEEP and 300 $\mathrm{g}$ of masonry cement. The shell was prepared in three layers. Between layers the waiting time for cement setting was of 24 $\mathrm{h}$. In addition, between each layer, particles were screened with a $4.8 \mathrm{~mm}$ sieve (4 mesh)

${ }^{2}$ The percentage is relative to the amount of WEEEP.

\section{Chemical analyses}

Quantitative analyses of organic compounds were performed by gas chromatography using a Shimadzu GC-2010 gas chromatograph with flame ionization detector, equipped with a VF-5ms column $(30 \mathrm{~m} \times 0.25 \mathrm{~mm} \times 0.25 \mu \mathrm{m})$ using $\mathrm{N}_{2}$ as gas carrier. Quantification of TBBPA was made using the internal standard calibration method $\left(\mathrm{r}^{2}>0.99\right)$ 
with authentic samples. Limit of detection (LOD $=$ $84 \mathrm{mg} / \mathrm{L}$ ) was calculated using the standard deviation of the residuals from the calibration curve (three times this standard deviation). Two internal standards were used, thus the LOD informed was a mean of these two calibrations. Limit of quantification (LOQ $=279 \mathrm{mg} / \mathrm{L}$ ) was calculated using the standard deviation of the residuals from the calibration curve (10 times this standard deviation).

Pore water from the cured process of the RPAs was obtained with the following procedure: immersion of RPA containing $250 \mathrm{~g}$ of WP in $500 \mathrm{~mL}$ of milli-Q water for 14 days at room temperature $\left(25^{\circ} \mathrm{C}\right)$ without stirring. Then the RPA (solid) was filtered and the solution was acidified with concentrate hydrochloric acid at $\mathrm{pH}=2$. The aqueous phase was extracted with $n$-hexane $(4 \times 125 \mathrm{~mL})$, the organic phase was dried with sodium sulphate, and the solvent was evaporated in vacuum. Standards were added to the organic phase and it was dissolved in ethyl acetate $(10 \mathrm{~mL})$; the organic compounds (TBBPA and BPA) were quantified by GC-FID using an internal standard method.

Iodine number determination was carried out for all carbon samples by a titration method described in the ASTM D 4607 standard (ASTM 2006). The values are shown in table II.

TABLE II. IODINE NUMBER AND SPECIFIC SURFACE AREA OF THE ACTIVATED CARBON SAMPLES.

\begin{tabular}{llccc}
\hline Entry & Sample & Manufacturer & $\begin{array}{c}\text { Iodine } \\
\text { number }\end{array}$ & $\begin{array}{c}\mathrm{S}_{\mathrm{BET}}{ }^{2} \\
\left(\mathrm{~m}^{2} / \mathrm{g}\right)\end{array}$ \\
\hline 1 & CAE 061 & Clarimex & 552 & 544 \\
2 & MMF & Clarimex & 764 & 755 \\
3 & CAE Ultra & Clarimex & 792 & 783 \\
4 & CLARISORB B & Clarimex & 794 & 785 \\
5 & Merck & Merck & 777 & 768 \\
6 & Vegetal & Local supplier & 124 & 112 \\
\hline
\end{tabular}

${ }^{1}$ Determined according to the ASTM D 4607 standard (ASTM 2006).

${ }^{2}$ Specific surface area $\left(\mathrm{S}_{\mathrm{BET}}\right)$ estimated from the iodine number $(\mathrm{IN}): \mathrm{S}_{\mathrm{BET}}=(0.9946 \times \mathrm{IN})-4.91$ (Mianowski et al. 2007).

\section{RESULTS AND DISCUSSION}

\section{RPAs manufacturing}

The main polymers in WEEEP samples were HIPS (34.5\%), ABS (62.0\%) and ABS/PC (2.2\%), which were determined by FT-IR in a previous report (Peisino et al. 2019). Better results in term of shapes and size homogeneity were achieved when three layers of cementitious covering were applied (Gómez et al. 2020). Then, RPAs were prepared according to Gómez et al. (2020). The identity of the activated charcoal used, and the dosage were modified to obtain samples that allowed establishing the most effective stabilization dosage for each activated carbon assayed.

\section{Iodine number}

The iodine number (IN) is the mass of iodine (in milligrams) consumed by $1 \mathrm{~g}$ of a chemical substance, commonly used to estimate the insaturation grade of oils and fatty acids, but it is also related to the porous characteristics of sorbents materials such as activated carbon, and fly ash, among others (Mianowski et al. 2007). Although the sorbent capability of a substance depends on variables such as porosity, $\mathrm{pH}$, zeta potential, and temperature, for the proposed use conditions of the activated carbon, it is more related to porosity, since $\mathrm{pH}$ would be determined by the cement matrix and temperature is difficult to control and monitor in the production of construction materials (Mianowski et al. 2007).

In addition, a specific surface area can be estimated from the IN values, according to Mianowski et al. (2007).

As can be observed on table II, it is possible to divide the activated carbons employed in three categories: low IN (Vegetal), medium IN (CAE 061) and high IN (the rest of the carbons tested). This means that Vegetal charcoal is the less porous, while Merck, MMF, CAE Ultra and Clarisorb B had the highest porous character.

\section{Chemical analysis}

TBBPA has two ionizable aromatic hydroxyl groups $\left(\mathrm{pKa} 1=7.5\right.$ and $\left.\mathrm{pKa}_{2}=8.5\right)($ Bergman et al. 2012). When TBBPA is in contact with cement shell, which is a well-known strong base (Birchall et al. 1978), it reacts immediately to form the anionic species of TBBPA (Fig. 1), thus increasing leaching to the aqueous phase. The same behavior applies to BPA, which is also a phenol.

Table III shows the concentrations of organic compounds for each leachate measured by CG-FID analysis. Figure 2 shows data from table III represented in a graphic bar. From the analysis of table III and figure 2 it appears that all activated carbons tested, in the proposed dosages (1.1 to $4.3 \%$ ), produce leachates below the LOD for TBBPA. This is consistent with the high value and specific surface area estimated by IN for these carbons. Activated carbon with a specific surface area of $896 \mathrm{~m}^{2} / \mathrm{g}$ determined 


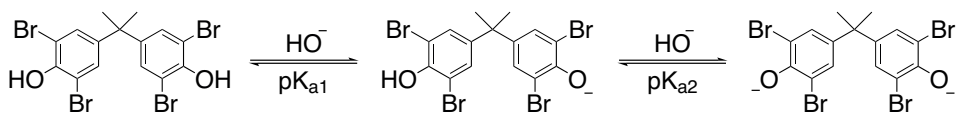

Fig. 1. Acid-base equilibrium of tetrabomobisphenol-A (TBBPA).

TABLE III. ORGANIC COMPOUND EXTRACTION OF DIFFERENT RECYCLED PLASTIC AGGREGATES (RPAs) ${ }^{1}$.

\begin{tabular}{|c|c|c|c|c|}
\hline Entry & Sample & {$[\mathrm{TBBPA}]^{2}$} & $\mathrm{TBBPA}^{3}$ & $\mathrm{BPA}^{4}$ \\
\hline 1 & WP@MC & $(105 \pm 2)$ & $(41.8 \pm 0.7)$ & 1.00 \\
\hline 2 & WP@MC:CAE-1 & $<\mathrm{LOD}^{5}$ & $<$ LOD & 0.48 \\
\hline 3 & WP@MC:CAE-2 & $<$ LOD & $<$ LOD & 0.63 \\
\hline 4 & WP@MC:CAE-3 & $<$ LOD & $<\mathrm{LOD}$ & 0.90 \\
\hline 5 & WP@MC:CAE-4 & $<$ LOD & $<\mathrm{LOD}$ & 0.48 \\
\hline 6 & WP@MC:MMF-1 & $<$ LOD & $<$ LOD & 0.60 \\
\hline 7 & WP@MC:MMF-2 & $<$ LOD & $<$ LOD & 0.45 \\
\hline 8 & WP@MC:MMF-3 & $<$ LOD & $<\mathrm{LOD}$ & 0.33 \\
\hline 9 & WP@MC:MMF-4 & $<$ LOD & $<\mathrm{LOD}$ & 0.33 \\
\hline 10 & WP@MC:CAEU-1 & $<$ LOD & $<$ LOD & 0.48 \\
\hline 11 & WP@MC:CAEU-2 & $<$ LOD & $<$ LOD & 0.29 \\
\hline 12 & WP@MC:CAEU-3 & $<$ LOD & $<$ LOD & 0.27 \\
\hline 13 & WP@MC:CAEU-4 & $<$ LOD & $<\mathrm{LOD}$ & $\mathrm{nd}^{6}$ \\
\hline 14 & WP@MC:CLARI-1 & $<$ LOD & $<\mathrm{LOD}$ & 0.46 \\
\hline 15 & WP@MC:CLARI-2 & $<$ LOD & $<$ LOD & 0.37 \\
\hline 16 & WP@MC:CLARI-3 & $<$ LOD & $<$ LOD & 0.22 \\
\hline 17 & WP@MC:CLARI-4 & $<$ LOD & $<\mathrm{LOD}$ & 0.37 \\
\hline 18 & WP@MC:MERCK-1 & $<$ LOD & $<$ LOD & 0.41 \\
\hline 19 & WP@MC:MERCK-2 & $<\mathrm{LOD}$ & $<$ LOD & 0.32 \\
\hline 20 & WP@MC:MERCK-3 & $<\mathrm{LOD}$ & $<$ LOD & 0.04 \\
\hline 21 & WP@MC:MERCK-4 & $<\mathrm{LOD}$ & $<$ LOD & 0.03 \\
\hline 22 & WP@MC:VEG-1 & $(100.0 \pm 0.3)$ & $(40.0 \pm 0.1)$ & 1.06 \\
\hline 23 & WP@MC:VEG-2 & $(85.0 \pm 0.5)$ & $(34.0 \pm 0.2)$ & 0.88 \\
\hline 24 & WP@MC:VEG-3 & $(63.5 \pm 0.5)$ & $(25.4 \pm 0.2)$ & 0.85 \\
\hline 25 & WP@MC:VEG-4 & $(58.3 \pm 0.5)$ & $(23.3 \pm 0.2)$ & 0.86 \\
\hline 26 & WP@MC:VEG-19 & $<\mathrm{LOQ}^{\mathrm{e}}$ & $<\mathrm{LOQ}$ & 0.70 \\
\hline 27 & WP@MC:VEG-31 & $<\mathrm{LOD}$ & $<\mathrm{LOD}$ & 0.15 \\
\hline
\end{tabular}

${ }^{1}$ Water for curing the RPA. Immersion of RPA containing $250 \mathrm{~g}$ of WEEEP in $500 \mathrm{~mL}$ of milli-Q water for 14 days at $25^{\circ} \mathrm{C}$ without stirring was performed. ${ }^{2}$ Concentration of TBBPA (x $\left.10^{1} \mathrm{mg} / \mathrm{L}\right)$ in the concentrated solution (total volume of $10 \mathrm{~mL}$ ).

${ }^{3}$ TBBPA leachate from samples in $\mathrm{mg}_{\text {TBBPA }} / \mathrm{kg}_{\text {WEEEP }}(\mathrm{mg} / \mathrm{kg})$.

${ }^{4} \mathrm{BPA}$ leachate from samples relative to WP@MC.

${ }^{5} \mathrm{LOD}=84 \mathrm{mg} / \mathrm{L}, \mathrm{LOQ}=279 \mathrm{mg} / \mathrm{L}$.

${ }^{6}$ Not determined.

by BET was one of the most effective sorbents used for the removal of BPA from aqueous solutions in a study carried out by Zhou et al. (2012). This is in a good agreement with the efficiency that we obtained for activated carbons with specific surface area values between 500 to $800 \mathrm{~m}^{2} / \mathrm{g}$ for the leaching of TBBPA and BPA in pore waters. Taking into account these results, we propose that a dosage of $1.1 \%$ for all the activated carbons, which has an IN greater than
500 , is effective for the stabilization of TBBPA and to prevent its leaching to cure waters, and eventually to the environment.

On the other hand, it can be observed that the non-activated vegetal charcoal does not perform as well as other carbons, which is totally in agreement with the low IN and specific surface area shown in table II, and with the fact that this charcoal lacks an activation process. 


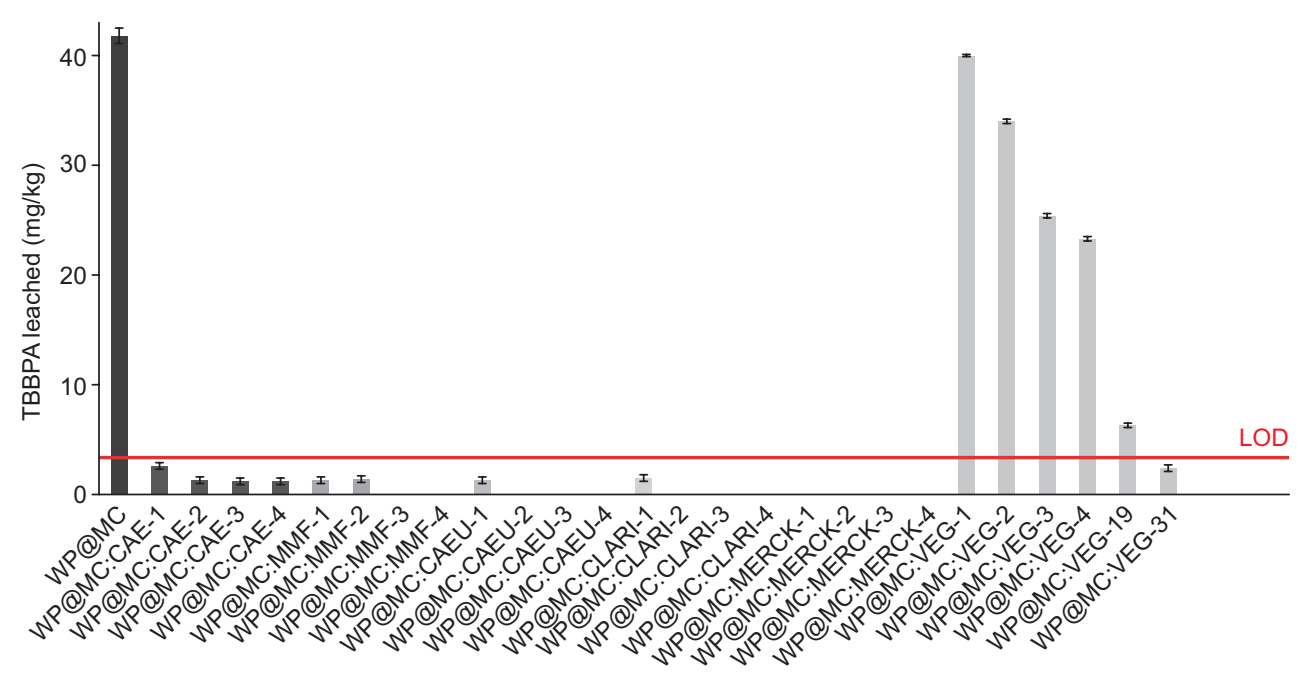

Fig. 2. Tetrabomobisphenol-A (TBBPA) leached in curing water of the different RPA.

Considering these findings, it can be said that for charcoals with low IN and specific surface area (IN lower than 150), an effective dosage in the production of RPAs must be of at least $31.3 \%$, which can be seen in more detail in figure 3 .

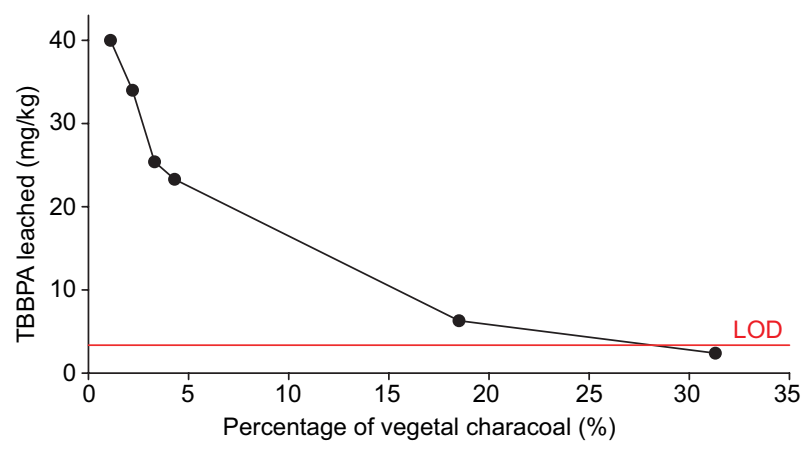

Fig. 3. Tetrabomobisphenol-A(TBBPA) leached in curing water of the different RPA covered with increasing percentages of "Vegetal" charcoal.

Figure 4 shows a relative quantification of BPA leached from the curing waters. The general tendency for the stabilization of BPA, the amount of activated carbon used in the production of RPAs is similar to that observed in TBBPA. The greater the dosage, the lower the BPA leached. However, it is important to notice that while all activated carbons show similar behaviors, the Merck carbon proved to be more effective for the stabilization of BPA, though its IN or specific surface area is not the largest of all tested carbons. This could be evidence that, to some degree, other parameters such as the zeta potential or temperature can affect the efficiency of coal as a stabilizing agent. Still, it has been proven that IN is a robust parameter to anticipate the performance of a given carbon for stabilizing BFRs in the production of RPAs.

For the use of non-activated vegetal charcoal, the analysis of BPA leaching in pore waters was similar to the one observed for TBBPA. The amount of BPA leached in dosages of 1.1 to $18.5 \%$ is considerable, but it can be said that in the dosage of $31.3 \%$ stabilization of BPA is efficient.

\section{CONCLUSIONS}

In this work we used several activated carbons to produce RPAs with the plastic fraction of WEEE. Through chemical analysis and GC-FID we were able to measure the amount of TBBPA and BPA leached.

The IN was determined for each type of activated carbon used. Based on our findings, we can state that all carbons assayed with an IN higher than 500 can be used in a proportion of $1.1 \%$ in the dosage for the production of RPAs with an effective stabilization of the organic contaminant present in the polymer matrix (BFR). Even though the IN is not related directly to the sorbent capability of the 


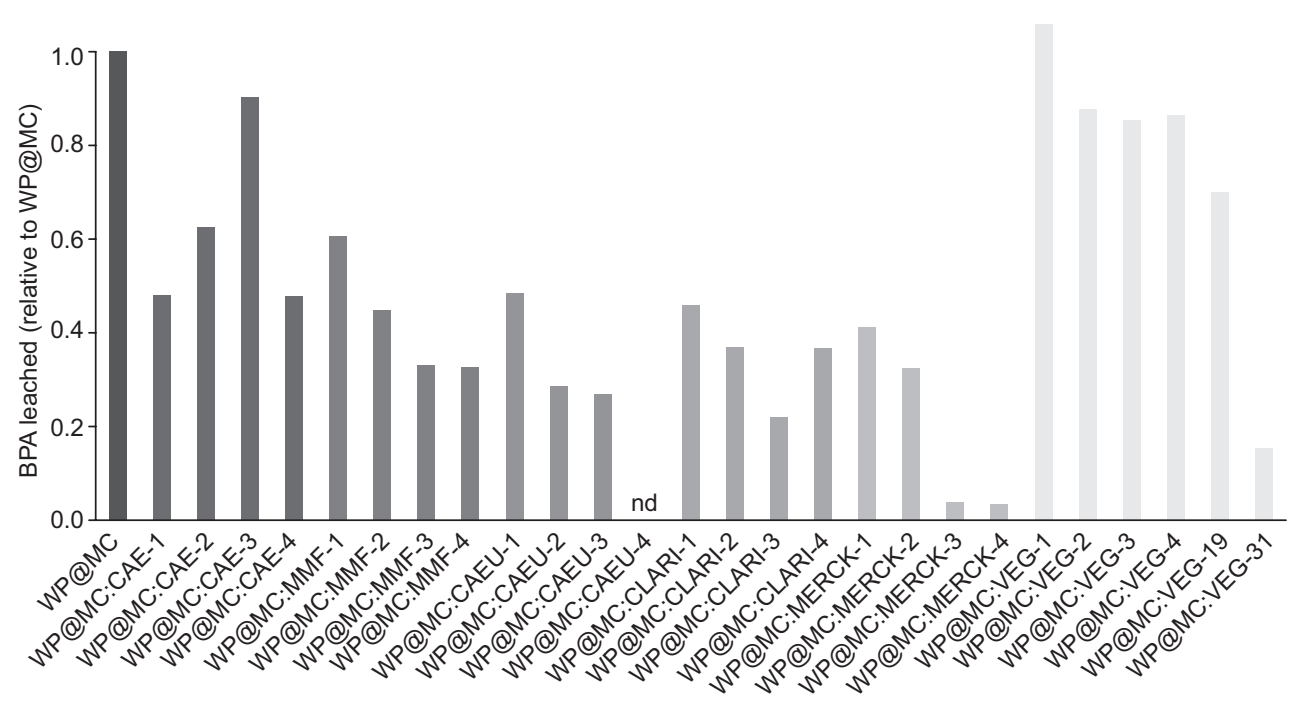

Fig. 4. Relative amount of bisphenol-A (BPA) leached in curing water of the different RPAs.

substance, but rather to its porosity, this index can be useful to predict the dosage needed for using a carbon not previously assayed, only by its simple and rapid determination.

Although vegetal non-activated charcoal needs to be added in a higher percentage $(31.3 \%)$ due to its low porosity (determined by the IN), this material can be easily obtained from a traditional charcoal factory. It is important to notice that charcoal was not subjected to an activation process, so it was unnecessary to use a power demanding processes like vapor treatments or acids. For this reason, the use of charcoal represents a more environmentally friendly, robust, and less expensive option for local ventures or cooperatives that want to implement the new proposed technology .

In further experiments we will study the effect of CA in the setting cement reaction. This will be crucial to determine the feasibility of using vegetable carbon in such high dosages.

\section{ACKNOWLEDGMENTS}

The authors would like to thank the Experimental Center for Economical Housing (CEVE) and the National Council of Scientific and Technological Research (CONICET). We are grateful to the Ministry of Science and Technology of Córdoba for financial support. A. C. gratefully acknowledges the receipt of a fellowship from CONICET.

\section{REFERENCES}

Alqahtani F.K., Khan M.I. and Ghataora, G. (2014). US8921463B1. Synthetic aggregate for use in concrete (patent). December.

Alqahtani F.K., Ghataora G., Khan M.I. and Dirar S. (2017a). Novel lightweight concrete containing manufactured plastic aggregate. Constr. Build. Mater. 148, 386-397. https://doi.org/10.1016/j.conbuildmat.2017.05.011

Alqahtani F.K., Khan M.I., Ghataora G. and Dirar S. (2017b). Production of recycled plastic aggregates and its utilization in concrete. J. Mater. Civ. Eng. 29(4), 4016248. https://doi.org/10.1061/(ASCE)MT.19435533.0001765

ASTM (2006). ASTM 4607. Standard test method for determination of iodine number of activated carbon. American Society for Testing and Materials.

Bergman Å., Rydén A., Law R.J., de Boer J., Covaci A., Alaee M., Birnbaum L., Petreas M., Rose M., Sakai S., van den Eede N. and van der Veen I. (2012). A novel abbreviation standard for organobromine, organochlorine and organophosphorus flame retardants and some characteristics of the chemicals. Environ. Int. 49, 57-82. https://doi.org/10.1016/j.envint.2012.08.003

Birchall J.D., Howard A.J. and Bailey J.E. (1978). On the hydration of Portland cement. Proc. R. Soc. A Math. Phys. Eng. Sci. 360, 445-453. https://doi.org/10.1098/ rspa.1974.0120

Buekens A. and Yang J. (2014). Recycling of WEEE plastics: a review. J. Mater. Cycles Waste Manag. 16, 415-434. https://doi.org/10.1007/s10163-014-0241-2 
Covaci A., Gerecke A.C., Law R.J., Voorspoels S., Kohler M., Heeb N. V., Leslie H., Allchin C.R. and de Boer J. (2006). Hexabromocyclododecanes (HBCDs) in the environment and humans: a review. Environ. Sci. Technol. 40, 3679-3688. https://doi.org/10.1021/es0602492

Darnerud P. (2003). Toxic effects of brominated flameretardants in man and in wildlife. Environ. Int. 29, 841853. https://doi.org/10.1016/S0160-4120(03)00107-7

Dimitrakakis E., Janz A., Bilitewski B. and Gidarakos E. (2009a). Small WEEE: determining recyclables and hazardous substances in plastics. J. Hazard. Mater. 161, 913-919. https://doi.org/10.1016/j. jhazmat.2008.04.054

Dimitrakakis E., Janz A., Bilitewski B. and Gidarakos E. (2009b). Determination of heavy metals and halogens in plastics from electric and electronic waste. Waste Manag. 29, 2700-2706. https://doi.org/10.1016/j.wasman.2009.05.020

Dunnick J.K., Morgan D.L., Elmore S.A., Gerrish K., Pandiri A., Ton T.V., Shockley K.R. and Merrick B.A. (2017). Tetrabromobisphenol A activates the hepatic interferon pathway in rats. Toxicol. Lett. 266, 32-41. https://doi.org/10.1016/j.toxlet.2016.11.019

Gómez M., Peisino L.E., Kreiker J., Gaggino R., Cappelletti A.L., Martín S.E., Uberman P.M., Positieri M. and Raggiotti B.B. (2020). Stabilization of hazardous compounds from WEEE plastic: development of a novel core-shell recycled plastic aggregate for use in building materials. Constr. Build. Mater. 230, 116977. https://doi.org/10.1016/j.conbuildmat.2019.116977

Gu L. and Ozbakkaloglu T. (2016). Use of recycled plastics in concrete: a critical review. Waste Manag. 51, 19-42. https://doi.org/10.1016/j.wasman.2016.03.005

Hannawi K., Kamali-Bernard S. and Prince W. (2010). Physical and mechanical properties of mortars containing PET and PC waste aggregates. Waste Manag. 30, 2312-2320. https://doi.org/10.1016/j.wasman.2010.03.028

Ilankoon I.M.S.K., Ghorbani Y., Chong M.N., Herath G., Moyo T. and Petersen J. (2018). E-waste in the international context - A review of trade flows, regulations, hazards, waste management strategies and technologies for value recovery. Waste Manag. 82, 258-275. https://doi.org/10.1016/j.wasman.2018.10.018

Laine J. and Yunes S. (1992). Effect of the preparation method on the pore size distribution of activated carbon from coconut shell. Carbon 30, 601-604. https://doi. org/10.1016/0008-6223(92)90178-Y

Lakshmi R. and Nagan S. (2010). Studies on concrete containing E plastic waste. Int. J. Environ. Sci. 1, 270-281.

Lakshmi R. and Nagan S. (2011). Investigations on durability characteristics of e-plastic waste incorporated concrete. Asian J. Civ. Eng. 12, 773-787.
Law K., Halldorson T., Danell R., Stern G., Gewurtz S., Alaee M., Marvin C., Whittle M. and Tomy G. (2006). Bioaccumulation and trophic transfer of some brominated flame-retardants in a lake Winnipeg (Canada) food web. Environ. Toxicol. Chem. 25, 2177. https:// doi.org/10.1897/05-500R.1

Luhar S. and Luhar I. (2019). Potential application of E-wastes in construction industry: a review. Constr. Build. Mater. 203, 222-240. https://doi.org/10.1016/j. conbuildmat.2019.01.080.

Maris E., Botané P., Wavrer P. and Froelich D. (2015). Characterizing plastics originating from WEEE: a case study in France. Miner. Eng. 76, 28-37. https:// doi.org/10.1016/j.mineng.2014.12.034

Meironyte D., Noren K. and Bergman A. (1999). Analysis of polybrominated diphenyl ethers in Swedish human milk. A time-related trend study, 1972-1997. J. Toxicol. Environ. Heal. Part A. 58, 329-341. https://doi. org/10.1080/009841099157197

Mianowski A., Owczarek M. and Marecka A. (2007). Surface area of activated carbon determined by the iodine adsorption number. Energ. Source. Part A 29, 839-850. https://doi.org/10.1080/00908310500430901

Nowek M. (2016). Performance of sand-lime products made with plastic waste. E3S Web Conf. 10, 66. https:// doi.org/10.1051/e3sconf/20161000066

Peeters J.R., Vanegas P., Tange L., van Houwelingen J. and Duflou J.R. (2014). Closed loop recycling of plastics containing flame retardants. Resour. Conserv. Recycl. 84, 35-43. https://doi.org/10.1016/j.resconrec.2013.12.006

Peisino L.E., Gómez M., Kreiker J., Gaggino R. and Angelelli M. (2019). Metal leaching analysis from a core-shell WEEE plastic synthetic aggregate. Sustain. Chem. Pharm. 12, 100134. https://doi.org/10.1016/j. scp. 2019.100134

Saikia N. and de Brito J. (2012). Use of plastic waste as aggregate in cement mortar and concrete preparation: a review. Constr. Build. Mater. 34, 385-401. https:// doi.org/10.1016/j.conbuildmat.2012.02.066

Schlummer M., Brandl F., Mäurer A. and van Eldik R. (2005). Analysis of flame retardant additives in polymer fractions of waste of electric and electronic equipment (WEEE) by means of HPLC-UV/MS and GPC-HPLC-UV. J. Chromatogr. A 1064, 39-51. https:// doi.org/10.1016/j.chroma.2004.12.016

Schlummer M., Mäurer A., Leitner T. and Spruzina W. (2006). Report: Recycling of flame-retarded plastics from waste electric and electronic equipment (WEEE). Waste Manag. Res. 24, 573-583. https://doi. org/10.1177/0734242X06068520

Schlummer M., Gruber L., Mäurer A., Wolz G. and Van Eldik R. (2007). Characterization of polymer fractions 
from waste electrical and electronic equipment (WEEE) and implications for waste management. Chemosphere 67, 1866-1876. https://doi.org/10.1016/j. chemosphere.2006.05.077

Senthil-Kumar K. and Baskar K. (2015a). Development of ecofriendly concrete incorporating recycled highimpact polystyrene from hazardous electronic waste. J. Hazard. Toxic Radiac. Waste 19, 4014042. https://doi. org/10.1061/(ASCE)HZ.2153-5515.0000265

Senthil-Kumar K. and Baskar K. (2015b). Recycling of E-plastic waste as a construction material in developing countries. J. Mater. Cycles Waste 17, 718-724. https:// doi.org/10.1007/s10163-014-0303-5

Senthil-Kumar K. and Baskar K. (2015c). Briefing: shear strength of concrete with E-waste plastic. Proc. Inst. Civ. Eng.-Constr. Mater. 168, 53-56. https://doi. org/10.1680/coma.14.00044

Senthil-Kumar K., Gandhimathi R. and Baskar K. (2016). Assessment of heavy metals in leachate of concrete made with e-waste plastic. Adv. Civ. Eng. Mater. 5, 20160003. https://doi.org/10.1520/ACEM20160003

Senthil-Kumar K. and Baskar K. (2018). Effect of temperature and thermal shock on concrete containing hazardous electronic waste. J. Hazard. Toxic Radiac. Waste. 22, 4017028. https://doi.org/10.1061/(ASCE) HZ.2153-5515.0000387

Siddique R., Khatib J. and Kaur I. (2008). Use of recycled plastic in concrete: a review. Waste Manag. 28, 18351852. https://doi.org/10.1016/j.wasman.2007.09.011

Stenvall E., Tostar S., Boldizar A., Foreman M.R. and Möller K. (2013). An analysis of the composition and metal contamination of plastics from waste electrical and electronic equipment (WEEE). Waste Manage. 33, 915-922. https://doi.org/10.1016/j.wasman.2012.12.022

Tamaddon F. and Hogland W. (1993). Review of cadmium in plastic waste in Sweden. Waste Manage. Res. 11, 287-295. https://doi.org/10.1006/wmre.1993.1031

Tan Q., Dong Q., Liu L., Song Q., Liang Y. and Li J. (2017). Potential recycling availability and capacity assessment on typical metals in waste mobile phones: a current research study in China. J. Clean. Prod. 148, 509-517. https://doi.org/10.1016/j. jclepro.2017.02.036

Wäger P.A., Schluep M., Müller E. and Gloor R. (2012). RoHS regulated substances in mixed plastics from waste electrical and electronic equipment. Environ. Sci. Technol. 46, 628-635. https://doi.org/10.1021/ es202518n

Wang R. and Meyer C. (2012). Performance of cement mortar made with recycled high impact polystyrene. Cem. Concr. Compos. 34, 975-981. https://doi. org/10.1016/j.cemconcomp.2012.06.014

Yang R.T. (2003). Adsorbents: fundamentals and applications. John Wiley \& Sons, 424 pp.

Yin C., Aroua M. and Daud W. (2007). Review of modifications of activated carbon for enhancing contaminant uptakes from aqueous solutions. Sep. Purif. Technol. 52, 403-415. https://doi.org/10.1016/j.seppur.2006.06.009

Zhou Y., Lu P. and Lu J. (2012). Application of natural biosorbent and modified peat for bisphenol a removal from aqueous solutions. Carbohydr. Polym. 88, 502508. https://doi.org/10.1016/j.carbpol.2011.12.034 